\title{
The Erythropoietin Effect on Uterus Congestion after Uterine Ischemia Reperfusion
}

\author{
Tsompos $C^{1}$, Panoulis $C^{2}$, Toutouzas $K^{3}$, Triantafyllou $A^{4}$, Zografos $\mathrm{G}^{3}$, and Papalois $\mathrm{A}^{5}$ \\ ${ }^{1}$ Department of Obstetrics and Gynecology, Mesologi County Hospital, Mesologi, Etoloakarnania, Greece \\ ${ }^{2}$ Department of Obstetrics and Gynecology, Aretaieion Hospital, Athens University, Athens, Attiki, Greece \\ ${ }^{3}$ Department of Surgery, Ippokrateion General Hospital, Athens University, Athens, Attiki, Greece \\ ${ }^{4}$ Department of Biologic Chemistry, Athens University, Athens, Attiki, Greece \\ ${ }^{5}$ Experimental Research Centre ELPEN Pharmaceuticals, S.A. Inc, Co, Pikermi, Attiki, Greece
}

Corresponding author: Tsompos Constantinos, Mesologi County Hospital, Greece, Tel: 00302631360237, 00306946674264; Fax: 00302106811215; E-mail: Tsomposconstantinos@gmail.com

Received Date: December 22, 2016; Accepted Date: January 18, 2017; Published Date: January 23, 2017

Citation: Tsompos C, Panoulis C, Toutouzas K, et al. The Erythropoietin Effect on Uterus Congestion after Uterine Ischemia Reperfusion. Transl Biomed. 2017, 8:1.

\section{Abstract}

Objective: This experiment investigated the erythropoietin (Epo) effect after uterine ischemiareperfusion (IR) in rats. The effect of Epo was evaluated studying the mean uterine congestion (UC) lesions.

Materials and methods: The mean weight of 40 rats used in the study was $247.7 \mathrm{~g}$. The UC lesions were estimated for the groups $A$ and $C$ on 60 min and for the groups $B$ and D on 120 min after reperfusion. Only the groups $C$ and D were administered by Epo.

Results: Epo administration non-significantly declined the UC lesions scores by (without lesions) 0.15 $(-0.5595137-0.2595137) \quad(p=0.4545)$. Reperfusion time non-significantly raised the UC lesions scores by (without lesions) $\quad 0.15 \quad(-0.5676974-0.3676974) \quad(P=0.5058)$. However, the combined Epo administration with reperfusion time non-significantly declined the UC lesions scores by (without lesions) 0.0090909 $(-0.2577992-0.2396174)(p=0.9414)$.

Conclusions: The Epo administration presented a nonsignificantly declining short-term effect on UC lesions scores. Perhaps, a higher Epo dosage and/or an experimental time lasting longer than 2 hours may reveal more significant efficacies.

Keywords: Ischemia; Erythropoietin; Uterus congestion lesions; Reperfusion

\section{Introduction}

Erythropoietin (Epo) belongs to the most occupied growth factor in biomedical studies. It implicates over 29,207 such studies at present; the $3.45 \%$ at least of which concern tissue ischemia-reperfusion (IR) models. A popular aim of Epo usage is the reverse potency of IR transient injuries of organs, including their tissues and certainly patients' health. However, satisfactory responses have not yet been received concerning basic affairs, such as, the dosage height, the administration timing, and the action velocity. The knowledge must be promoted besides the original action of Epo in red blood cells production. These specific matters require more detailed management. A numeric estimation of Epo trends was revealed by a meta-analysis of 33 published studies concerning serum variables, yielded by the present experiment (Table 1).

Table 1 The erythropoietin (Epo) influence ( $\pm S D$ ) on the levels of some seric [1] variables concerning reperfusion (rep) time.

\begin{tabular}{|c|c|c|c|c|c|c|c|c|}
\hline Variable & 1h rep & $\begin{array}{l}\mathrm{p}- \\
\text { value }\end{array}$ & $1.5 \mathrm{~h}$ rep & p-value & $2 \mathrm{~h}$ rep & p-value & $\begin{array}{l}\text { Interaction of Epo } \\
\text { and rep }\end{array}$ & p-value \\
\hline $\begin{array}{l}\text { White } \\
\text { BCC }\end{array}$ & $+24.01 \% \pm 13.38 \%$ & 0.1012 & $+22.09 \% \pm 9.11 \%$ & 0.0163 & $+20.17 \% \pm 12.94 \%$ & 0.0902 & $+14.63 \% \pm 5.40 \%$ & 0.008 \\
\hline Red BCC & $+1.45 \% \pm 3.31 \%$ & 0.6589 & $+0.37 \% \pm 3.02 \%$ & 0.9048 & $-0.70 \% \pm 4.68 \%$ & 0.8844 & $+0.81 \% \pm 1.79 \%$ & 0.6446 \\
\hline $\begin{array}{l}\text { Hematocri } \\
\mathrm{t}\end{array}$ & $+0.14 \% \pm 2.89 \%$ & 0.9626 & $-0.61 \% \pm 2.37 \%$ & 0.8072 & $-1.37 \% \pm 4.05 \%$ & 0.7485 & $+0.24 \% \pm 1.38 \%$ & 0.8586 \\
\hline
\end{tabular}




\begin{tabular}{|c|c|c|c|c|c|c|c|c|}
\hline $\begin{array}{l}\text { Hemoglob } \\
\text { in }\end{array}$ & $+4.09 \% \pm 5.20 \%$ & 0.335 & $+2.15 \% \pm 2.63$ & 0.4527 & $+0.20 \% \pm 5.08 \%$ & 0.9584 & $+1.31 \% \pm 1.59 \%$ & 0.3984 \\
\hline $\mathrm{MCH}$ & $+0.01 \% \pm 1.29 \%$ & 0.9904 & $+0.67 \% \pm 0.80 \%$ & 0.3549 & $+1.34 \% \pm 1.08 \%$ & 0.1509 & $-0.36 \% \pm 0.47 \%$ & 0.443 \\
\hline MCV & $+0.01 \% \pm 1.08 \%$ & 0.9904 & $+0.56 \% \pm 0.66 \%$ & 0.3549 & $+1.12 \% \pm 0.91 \%$ & 0.1509 & $+0.30 \% \pm 0.39 \%$ & 0.443 \\
\hline $\mathrm{MCHC}$ & $+1.82 \% \pm 0.56 \%$ & 0.0076 & $+1.73 \% \pm 0.50 \%$ & 0.0016 & $+1.65 \% \pm 0.92 \%$ & 0.0721 & $+0.89 \% \pm 0.31 \%$ & 0.0061 \\
\hline RBC DW & $-1.85 \% \pm 4.24 \%$ & 0.6703 & $-1.64 \% \pm 2.53 \%$ & 0.5159 & $-1.43 \% \pm 3.34 \%$ & 0.6078 & $-1.06 \% \pm 1.43 \%$ & 0.4733 \\
\hline Plt C & $-7.32 \% \pm 13.11 \%$ & 0.5219 & $-2.14 \% \pm 8.04 \%$ & 0.7581 & $+3.04 \% \pm 10.78 \%$ & 0.7204 & $-0.16 \% \pm 4.76 \%$ & 0.9725 \\
\hline MPV & $+3.82 \% \pm 4.10 \%$ & 0.3105 & $-0.12 \% \pm 2.13 \%$ & 0.9513 & $-4.07 \% \pm 3.75 \%$ & 0.2608 & $-0.27 \% \pm 0.92 \%$ & 0.7585 \\
\hline $\begin{array}{l}\text { Platelet } \\
\text { DW }\end{array}$ & $+1.60 \% \pm 0.80 \%$ & 0.0765 & $+1.36 \% \pm 0.58 \%$ & 0.0205 & $+1.13 \% \pm 0.74 \%$ & 0.1152 & $+0.37 \% \pm 0.37 \%$ & 0.0615 \\
\hline $\begin{array}{l}\text { Platelet- } \\
\text { crit }\end{array}$ & $-16.47 \% \pm 10.40 \%$ & 0.0921 & $-13.74 \% \pm 7.01 \%$ & 0.0158 & $-11.01 \% \pm 7.34 \%$ & 0.0882 & $-6.88 \% \pm 3.69 \%$ & 0.0615 \\
\hline Glucose & $+0.75 \% \pm 8.11 \%$ & 0.9307 & $+5.59 \% \pm 6.46 \%$ & 0.3208 & $+10.44 \% \pm 10.99 \%$ & 0.3491 & $+4.94 \% \pm 3.81 \%$ & 0.1892 \\
\hline Urea & $+21.42 \% \pm 7.84 \%$ & 0.0115 & $+20.11 \% \pm 7.25 \%$ & 0.0059 & $+18.80 \% \pm 9.44 \%$ & 0.0709 & $+15.64 \% \pm 4.04 \%$ & 0.0003 \\
\hline Creatinine & $-0.10 \% \pm 9.78 \%$ & 0.9904 & $-4.84 \% \pm 5.78 \%$ & 0.3721 & $-9.59 \% \pm 7.74 \%$ & 0.1509 & $-2.62 \% \pm 3.49 \%$ & 0.443 \\
\hline Uric acid & $+10.13 \% \pm 15.10 \%$ & 0.4917 & $+15.86 \% \pm 10.21 \%$ & 0.1408 & $+21.59 \% \pm 15.45 \%$ & 0.194 & $+9.33 \% \pm 6.16 \%$ & 0.1264 \\
\hline $\begin{array}{l}\text { Total } \\
\text { protein }\end{array}$ & $-0.02 \% \pm 2.47 \%$ & 0.9904 & $-1.27 \% \pm 1.51 \%$ & 0.3721 & $-2.52 \% \pm 2.03 \%$ & 0.1509 & $-0.68 \% \pm 2.48 \%$ & 0.443 \\
\hline Albumins & $-4.61 \% \pm 4.21 \%$ & 0.253 & $-9.28 \% \pm 3.20 \%$ & 0.0054 & $-13.96 \% \pm 5.03 \%$ & 0.0095 & $-5.37 \% \pm 2.73 \%$ & 0.0072 \\
\hline ALT & $+18.89 \% \pm 12.42 \%$ & 0.1372 & $+7.63 \% \pm 18.94 \%$ & 0.6396 & $-3.63 \% \pm 25.19 \%$ & 0.8617 & $+8.03 \% \pm 11.36 \%$ & 0.4698 \\
\hline AST & $+29.53 \% \pm 9.72 \%$ & 0.0096 & $+26.71 \% \pm 13.17 \%$ & 0.0235 & $+23.89 \% \pm 21.59 \%$ & 0.1709 & $+19.73 \% \pm 7.70 \%$ & 0.0119 \\
\hline yGT & $-19.35 \% \pm 18.58 \%$ & 0.2362 & $-12.70 \% \pm 13.11 \%$ & 0.3541 & $-6.06 \% \pm 19.96 \%$ & 0.78 & $-4.62 \% \pm 7.97 \%$ & 0.5534 \\
\hline ALP & $+0.20 \% \pm 18.57 \%$ & 0.9904 & $+10.70 \% \pm 12.78 \%$ & 0.3549 & $+21.20 \% \pm 17.11 \%$ & 0.1509 & $+5.79 \% \pm 7.72 \%$ & 0.443 \\
\hline ACP & $+0.06 \% \pm 5.79 \%$ & 0.9904 & $+3.11 \% \pm 3.71 \%$ & 0.3172 & $+6.16 \% \pm 4.97 \%$ & 0.1509 & $+1.68 \% \pm 2.23 \%$ & 0.443 \\
\hline CPK & $+0.15 \% \pm 14.09 \%$ & 0.9904 & $+7.91 \% \pm 9.44 \%$ & 0.3549 & $+15.67 \% \pm 12.65 \%$ & 0.1509 & $+4.28 \% \pm 5.70 \%$ & 0.443 \\
\hline CK-MB & $+0.08 \% \pm 7.90 \%$ & 0.9904 & $+4.28 \% \pm 5.11 \%$ & 0.3721 & $+8.49 \% \pm 6.85 \%$ & 0.1509 & $+2.32 \% \pm 3.09 \%$ & 0.443 \\
\hline $\mathrm{LDH}$ & $+0.08 \% \pm 7.92 \%$ & 0.9904 & $+4.48 \% \pm 5.35 \%$ & 0.3549 & $+8.89 \% \pm 7.17 \%$ & 0.1509 & $+2.42 \% \pm 3.22 \%$ & 0.443 \\
\hline Sodium & $+0.72 \% \pm 0.74 \%$ & 0.3054 & $+0.21 \% \pm 0.63 \%$ & 0.7136 & $-0.29 \% \pm 1.09 \%$ & 0.767 & $-0.11 \% \pm 0.38 \%$ & 0.7531 \\
\hline Potassium & $-6.17 \% \pm 4.94 \%$ & 0.154 & $-2.21 \% \pm 3.66 \%$ & 0.5134 & $+1.74 \% \pm 5.43 \%$ & 0.7299 & $+0.18 \% \pm 2.22 \%$ & 0.9338 \\
\hline Calcium & $0.28 \% \pm 1.19 \%$ & 0.8065 & $-0.56 \% \pm 1.13 \%$ & 0.5761 & $-1.41 \% \pm 2.08 \%$ & 0.41 & $-0.34 \% \pm 0.68 \%$ & 0.6095 \\
\hline $\begin{array}{l}\text { Phosphor } \\
\text { us }\end{array}$ & $+1.92 \% \pm 5.25 \%$ & 0.6982 & $+3.95 \% \pm 3.35 \%$ & 0.21 & $+5.98 \% \pm 4.81 \%$ & 0.293 & $+2.45 \% \pm 2.01 \%$ & 0.2168 \\
\hline $\begin{array}{l}\text { Magnesiu } \\
\mathrm{m}\end{array}$ & $+1 \% \pm 6.20 \%$ & 0.8596 & $-1.09 \% \pm 3.34 \%$ & 0.7248 & $-3.19 \% \pm 3.90 \%$ & 0.3729 & $-0.19 \% \pm 1.93 \%$ & 0.9197 \\
\hline Amylase & $+6.50 \% \pm 9.15 \%$ & 0.4161 & $+5.04 \% \pm 6.12 \%$ & 0.3831 & $+3.59 \% \pm 8.42 \%$ & 0.6649 & $+4.36 \% \pm 3.65 \%$ & 0.2258 \\
\hline $\begin{array}{l}\text { Progester } \\
\text { on }\end{array}$ & $-0.20 \% \pm 18.65 \%$ & 0.9904 & $-8.86 \% \pm 10.58 \%$ & 0.3549 & $-17.53 \% \pm 14.15 \%$ & 0.1509 & $-4.79 \% \pm 6.39 \%$ & 0.443 \\
\hline Mean & $+2.20 \% \pm 9.77 \%$ & 0.5742 & $+2.58 \% \pm 8.93 \%$ & 0.3823 & $+2.97 \% \pm 10.26 \%$ & 0.3554 & $+2.18 \% \pm 5.83 \%$ & 0.4148 \\
\hline
\end{tabular}

This experiment tried to estimate the Epo action on a rat setting of IR using the mean uterine congestion (UC) lesions scores.

\section{Materials and Methods}

\section{Animal preparation}

This biomedical research received the 3693/12 November 2010 and 14/10 January 2012 licenses by the East Attiki Prefecture Vet Address. Elpen Pharmaceuticals Co Inc SA 
granted all consumables, facilities and equipment at Pikermi, Attiki. Pure humanistic care was provided for Albino female Wistar rats. Pre-experimental normal housing included continuous ad libitum feeding in laboratory. Euthanasia excluded the post-experimental survival and preservation of the animals. The 40 rats were randomly assigned to four equal groups. The quoting protocols of IR were used: $45 \mathrm{~min}$ ischemia and then $60 \mathrm{~min}$ reperfusion for group $A ; 45 \mathrm{~min}$ ischemia and then 120 min reperfusion for group B; $45 \mathrm{~min}$ ischemia and then $60 \mathrm{~min}$ concurrent Epo (Epoetin, rhEpo ${ }_{\alpha}$, Janssen-Cilag, Beerse, Belgium) intravenous (IV) administration with reperfusion for group C; $45 \mathrm{~min}$ ischemia and then 120 min concurrent Epo IV administration with reperfusion for group D. The Epo dosage was assessed at $10 \mathrm{mg} / \mathrm{Kg}$ [1], mass per animal. Prenarcosis, general anesthesia, non-stop intraexperimental oxygen supply, electrocardiogram and acidometry are also confirmed in related references. Laparotomic clamping with forceps of inferior abdominal aorta over the renal arteries level, induced ischemia for $45 \mathrm{~min}$. The forceps removal was restoring the inferior aorta reperfusion patency. Blood flow exclusions were iterated for every animal. Epo was administered starting reperfusion via inferior vena cava catheter. The UC lesions scores were estimated at 60th min of reperfusion for $A$ and $C$ groups groups and at 120th min of reperfusion for $B$ and $D$ groups. 40 female Wistar brand albino rats with mean body mass (M:) of $247.7 \mathrm{~g}$ (Std. Dev[SD]: $36.59703 \mathrm{~g})$ were used. The mass range was fluctuated between $165 \mathrm{~g}$ and $320 \mathrm{~g}$. Rats' body mass could be practically a confusing factor, e.g. the more obese rats were supposed to have more pronounced UC lesions scores. This assumption was statistically investigated with grading of UC lesions findings. Detailed pathologic classification [2] was performed by scores: 0 without lesions, 1 mild ones, 2 moderate ones and 3 serious ones. The previous classification was transformed as: (0-0.499) without lesions, (0.5-1.499) the mild ones, (1.5-2.499) the moderate ones and (2.5-3) the serious one's scores since noninteger estimations were appeared. UC lesions scores were estimated by the 1st Pathology Department of ClinicalLaboratory Sector at Faculty of Medicine in Athens University.

\section{The Ischemia-Reperfusion Model}

\section{Control groups}

The 20 control rats with M: 252.5 g (SD: 39.31988 g) were submitted into ischemia lasting $45 \mathrm{~min}$ and then into reperfusion.

A group: Reperfusion lasting $60 \mathrm{~min}$ featured 10 control (placebo) rats of M: $243 \mathrm{~g}$ [SD: $45.77724 \mathrm{~g}$ ] and mean mild UC score 1.4 (SD: 0.5163978) (Table 2).

Table 2 Weight and uterus congestion (UC) score mean levels and Std. Dev. of groups.

\begin{tabular}{|l|l|l|l|}
\hline Groups & Variable & Mean & Std. Dev \\
\hline A & Weight & $243 \mathrm{~g}$ & $45.77724 \mathrm{~g}$ \\
\hline
\end{tabular}

\begin{tabular}{|l|l|l|l|}
\hline \multirow{2}{*}{ B } & UC & mild 1.4 & 0.516398 \\
\hline \multirow{2}{*}{ C } & Weight & $262 \mathrm{~g}$ & $31.10913 \mathrm{~g}$ \\
\cline { 2 - 4 } & UC & mild 1.1 & 0.316228 \\
\hline \multirow{2}{*}{ D } & Weight & $242.8 \mathrm{~g}$ & $29.33636 \mathrm{~g}$ \\
\cline { 2 - 4 } & UC & mild 0.9 & 0.567646 \\
\cline { 2 - 4 } & Weight & $243 \mathrm{~g}$ & $32.84644 \mathrm{~g}$ \\
\cline { 2 - 4 } & UC & mild 1.3 & 0.948683 \\
\hline
\end{tabular}

B group: Reperfusion lasting 120 min featured 10 control (placebo) rats of M: $262 \mathrm{~g}$ (SD: $31.10913 \mathrm{~g}$ ) and mean mild UC score 1.1 (SD: 0.3162278) (Table 2).

\section{Erythropoietin group}

The 20 Epo rats with mean mass $242.9 \mathrm{~g}$ (SD: $30.3105 \mathrm{~g}$ ) were submitted into ischemia lasting $45 \mathrm{~min}$ and then into reperfusion on its beginning $10 \mathrm{mg}$ Epol/ $\mathrm{kg}$ body mass were IV provided.

C group: Reperfusion lasting 60 min featured 10 Epo rats of M: $242.8 \mathrm{~g}$ (SD: $29.33636 \mathrm{~g}$ ) and mean mild UC score 0.9 (Std. Dev: 0.5676462) (Table 2).

D group: Reperfusion lasting 120 min featured 10 Epo rats of $\mathrm{M}: 243 \mathrm{~g}$ (SD: $32.84644 \mathrm{~g}$ ) and mean mild UC score 1.3 (SD: 0.9486833) (Table 2).

\section{Statistic Analysis}

The bodies mass and UC lesions scores columns were compared each other by the statistic standard t-test and by the statistic Wilcoxon signed-rank test respectively (Table 3).

Table 3 Statistical significance of mean values difference for groups (DG) after statistical standard t test application for weight and Wilcoxon signed-rank test for scores.

\begin{tabular}{|c|l|l|l|}
\hline \multirow{2}{*}{ DG } & Variable & Difference & p-value \\
\hline \multirow{2}{*}{ A-B } & Weight & $-19 \mathrm{~g}$ & 0.2423 \\
\cline { 2 - 4 } & UC & without lesions 0.3 & 0.0833 \\
\hline \multirow{2}{*}{ A-D } & Weight & $0.2 \mathrm{~g}$ & 0.99 \\
\cline { 2 - 4 } & UC & mild 0.5 & 0.0951 \\
\cline { 2 - 4 } & UC & $0 \mathrm{~g}$ & 1 \\
\hline \multirow{2}{*}{ B-C } & Weight & $19.2 \mathrm{~g}$ & 0.6547 \\
\cline { 2 - 4 } & UC & without lesions 0.2 & 0.2598 \\
\hline \multirow{2}{*}{ B-D } & Weight & $19 \mathrm{~g}$ & 0.3173 \\
\cline { 2 - 5 } & UC & without lesions-0.2 & 0.1011 \\
\hline \multirow{2}{*}{ C-D } & Weight & $-0.2 \mathrm{~g}$ & 0.9883 \\
\hline
\end{tabular}




\begin{tabular}{|l|l|l|l|}
\hline & UC & without lesions-0.4 & 0.3632 \\
\hline
\end{tabular}

Any raised significant difference among UC scores, was investigated whether being due to any significant mass one. The generalized linear models (GLM) test with dependent variable the UC scores and independent variables, first the drug Epo or no drug administration, second the reperfusion time and third both the interacted variables were applied. The statistic calculations were performed by the Stata 6.0 software (Stata 6.0, StataCorp LP SA, Texas, USA).

\section{Results}

The Epo administration non-significantly declined the UC scores by (without lesions) $0.15 \quad(-0.5595137-0.2595137)$ $(p=0.4629)$. This result was accordant with the one of Wilcoxon signed-rank test $(p=0.4461)$. The reperfusion time variable non-significantly augmented the UC scores by (without lesions) $0.05(-0.3621388-0.4621388) \quad(P=0.8073)$, nearly in accordance with one of Wilcoxon signed-rank test 0.25 $(-0.773256-0.273256)(P=0.2043)$. However, the interaction of Epo administration with reperfusion time non-significantly declined the UC scores by (without lesions) 0.0090909 ($0.2577992-0.2396174)(p=0.9414)$. The co-evaluation of the above results and Table 3, yields the Tables 4 and 5 regarding the declining influence of Epo vs reperfusion time.

Considering the rats' weight as a more independent variable of GLM, a non-significant correlation appeared ( $p=0.5769$ ).

Table 4 The alteration influence of erythropoietin in connection with reperfusion time.

\begin{tabular}{|c|c|c|c|c|}
\hline \multirow[b]{2}{*}{ Alteration } & \multirow[b]{2}{*}{$95 \%$ c. in. } & \multirow[b]{2}{*}{ Reperfusion time } & \multicolumn{2}{|l|}{ p-values } \\
\hline & & & Wilcoxon & GLM \\
\hline mild 0.5 & $-1.01966-0.0098314$ & $1 \mathrm{~h}$ & 0.0951 & 0.0541 \\
\hline without lesions 0.15 & $-0.5595137-0.2595137$ & $1.5 \mathrm{~h}$ & 0.4461 & 0.4629 \\
\hline without lesions- 0.2 & $-0.4643699-0.8643699$ & $2 \mathrm{~h}$ & 0.5948 & 0.535 \\
\hline without lesions +0.05 & $-0.3621388-0.4621388$ & reperfusion time & - & 0.8073 \\
\hline without lesions +0.25 & $-0.773256-0.273256$ & reperfusion time & 0.2043 & - \\
\hline without lesions- 0.0090909 & $-0.2577992-0.2396174$ & interaction & - & 0.9414 \\
\hline
\end{tabular}

Table 5 Synoptic presence of the alteration influence of erythropoietin in connection with reperfusion time.

\begin{tabular}{|c|c|c|c|}
\hline Alteration & $95 \%$ c. in. & $\begin{array}{l}\text { Reperfusion } \\
\text { time }\end{array}$ & $\begin{array}{l}p- \\
\text { value } \\
s\end{array}$ \\
\hline mild 0.5 & $\begin{array}{l}-1.009831-0.00983 \\
14\end{array}$ & $1 \mathrm{~h}$ & $\begin{array}{l}0.074 \\
6\end{array}$ \\
\hline without lesions 0.15 & $\begin{array}{l}-0.5595137-0.2595 \\
137\end{array}$ & $1.5 \mathrm{~h}$ & $\begin{array}{l}0.454 \\
5\end{array}$ \\
\hline without lesions- 0.2 & $\begin{array}{l}-0.4643699-0.8643 \\
699\end{array}$ & $2 \mathrm{~h}$ & $\begin{array}{l}0.564 \\
9\end{array}$ \\
\hline without lesions +0.15 & $\begin{array}{l}-0.5676974-0.3676 \\
974\end{array}$ & $\begin{array}{l}\text { reperfusion } \\
\text { time }\end{array}$ & $\begin{array}{l}0.505 \\
8\end{array}$ \\
\hline $\begin{array}{l}\text { without } \\
\text { lesions-0.0090909 }\end{array}$ & $\begin{array}{l}-0.2577992-0.2396 \\
174\end{array}$ & interaction & $\begin{array}{l}0.941 \\
4\end{array}$ \\
\hline
\end{tabular}

\section{Discussion}

The contribution of ischemia in UC is investigated. Salas postulated [3] that secondary compressing of cerebral congestion by the large uterus, diverts blood to the brain, causing eclamptic convulsions. Surcel et al. showed that uterus fibroma has always been accompanied by pelvic congestion inducing [4] experimentally estrogen tumors in animals. Douglas observed liver and renal glomerular congestion both in pregnant and non-pregnant rats producing [5] hypertension, however, only in pregnant ones. Thus, tissue congestion is associated with Epo in different tissues besides uterus. Rashed et al. proved short-term protective efficacy of Epo after vascular congestion [6] among other findings in rat testicular IR injury. McMurray et al. presented [7] the baseline characteristics of patients with $\alpha$-darbepoetin, long-term heart failure and signs of marked congestion. Lagarto et al. showed [8] signs of a minimal irritation consisting of weak edema with vascular congestion into the right nostril, after $15 \mu \mathrm{l}$ Epo administration; alike the one induced in Wistar rats brain during hypoxia. Zheng et al. got on [9] improving aortic stenosis patients' cardiac hypertrophy, pulmonary congestion and left ventricular dysfunction treating pre-operative aortic valve replacement with rhEpo administration in a mouse model. Piloto et al. implicated the heart failure as cause of sudden death when was present [10] with brain vascular congestion; left ventricular hypertrophy and elevated hematocrit in rats. Naito et al. implicated decreased serum Epo concentration for [11] the cardiac remodeling mechanisms induced by iron deficiency anemia promoting cardiac fibrosis and lung congestion. Kiris et al. proved [12] that Epo significantly decreased ( $P=0.05$ versus aortic $I R)$ the focal renoglomerular necrosis, the Bowman's capsule dilatation, the tubular epithelium degeneration, the tubular epithelium necrosis, interstitial tissues inflammatory cells infiltration and the blood vessels congestion upon aortic IR in rats. Minamishima et al. associated [13] the premature mortality with pronounced venous congestion and dilated cardiomyopathy in enzyme PHD2 lack mice. Lee et al. 
implicated [14] the red pulp congestion for splenomegaly in peroxiredoxins II-/- deficient mice, although healthy in appearance and fertility. Ruschitzka et al. treated [15] the acute left ventricular dilatation, vascular engorgement, pulmonary congestion and hemorrhage in polyglobulic transgenic mice overexpressing human Epo by NO synthase inhibitor. Gentz et al. implicated polycythemia 74\% for [16] pulmonary congestion due to high serum Epo concentration in a llama.

\section{Conclusion}

Epo administration generally short-term non-significantly declines the UC lesions scores. Perhaps, a higher Epo dose and/or an experimental time lasting longer than 2 hours may reveal more significant efficacies.

\section{Acknowledgment}

This study was funded by Scholarship by the Experimental Research Center ELPEN Pharmaceuticals (E.R.C.E), Athens, Greece. The research facilities for this project were provided by the Aforementioned Institution.

\section{References}

1. Tsompos C, Panoulis C, Toutouzas K, Triantafyllou A, Zografos G, et al. (2016) The acute effect of erythropoietin on mean platelet volume levels during hypoxia reoxygenation injury in rats. Med Bull Haseki 54: 199-206.

2. Osmanağaoğlu $M A$, Kesim $M$, Yuluğ $E$, Menteşe $A$, Karahan $S C$ (2012) Ovarian-protective effects of clotrimazole on ovarian ischemia/reperfusion injury in a rat ovarian-torsion model. Gynecol Obstet Invest 74: 125-130.

3. Salas SP (1999) What causes pre-eclampsia? Baillieres Best Pract Res Clin Obstet Gynaecol 13: 41-57.

4. Surcel VJ, Rotaru O, Toader S (1982) Experimental induction of uterus tumours by modification of localized vascularization. Zentralbl Gynakol 104: 669-677.

5. Douglas BH (1976) The rat as a model for preeclampsia. Perspect Nephrol Hypertens 5: 411-419.
6. Rashed FK, Ghasemi B, Deldade Mogaddam H, Mesgari M (2013) The effect of erythropoietin on ischemia/reperfusion injury after testicular torsion/detorsion: a randomized experimental study. ISRN Urol 2013: 351309.

7. McMurray JJ, Anand IS, Diaz R, Maggioni AP, O'Connor C, et al. (2013) RED-HF committees investigators. Baseline characteristics of patients in the reduction of events with darbepoetin alfa in heart failure trial (RED-HF). Eur J Heart Fail 15: 334-341.

8. Lagarto A, Bueno V, Guerra I, Valdés O, Couret M, et al. (2011) Absence of hematological side effects in acute and subacute nasal dosing of erythropoietin with a low content of sialic acid. Exp Toxicol Pathol 63: 563-567.

9. Zheng L, Xu J, Qiu W, Liu X, Zhao CM, et al. (2010) Cardioprotection of exogenous erythropoietin in mice with ligature-induced aortic stenosis: Effects on maladaptive cardiac hypertrophy. J Physiol Pharmacol 61: 13-20.

10. Piloto N, Teixeira HM, Teixeira-Lemos E, Parada B, Garrido P, et al. (2009) Erythropoietin promotes deleterious cardiovascular effects and mortality risk in a rat model of chronic sports doping. Cardiovasc Toxicol 9: 201-210.

11. Naito $\mathrm{Y}$, Tsujino T, Matsumoto $\mathrm{M}$, Sakoda $T$, Ohyanagi $M$, et al. (2009) Adaptive response of the heart to long-term anemia induced by iron deficiency. Am J Physiol Heart Circ Physiol 296: 585-593.

12. Kiris I, Kapan S, Kilbas A, Yilmaz N, Altuntaş I, et al. (2008) The protective effect of erythropoietin on renal injury induced by abdominal aortic-ischemia-reperfusion in rats. J Surg Res 149: 206-213.

13. Minamishima YA, Moslehi J, Bardeesy N, Cullen D, Bronson RT, et al. (2008) Somatic inactivation of the PHD2 prolyl hydroxylase causes polycythemia and congestive heart failure. Blood 111: 3236-3244.

14. Lee TH, Kim SU, Yu SL, Kim SH, Park DS, et al. (2003) Peroxiredoxin II is essential for sustaining life span of erythrocytes in mice. Blood 101: 5033-5038.

15. Ruschitzka FT, Wenger RH, Stallmach T, Quaschning T, de Wit C, et al. (2000) Nitric oxide prevents cardiovascular disease and determines survival in polyglobulic mice overexpressing erythropoietin. Proc Natl Acad Sci USA 97: 11609-11613.

16. Gentz EJ, Pearson EG, Lassen ED, Snyder SP, Sharpnack E (1994) Polycythemia in a llama. J Am Vet Med Assoc 204: 1490-1492. 